doc. PhDr. ThDr. Daniel Slivka, PhD.

\title{
Pamätné a sakrálne miesta súčasného judaizmu
}

\begin{abstract}
Jerusalem is one of the oldest cities in the world. It is considered holy to the three major Judaism, Christianity and Islam. Herodian quarter is art of the residential quarter, preserved from Herodian times. The Burnt House is an excavated house from the Second Temple period in the Jewish Quarter of the Old City of Jerusalem. The Burnt House is believed to have been set on fire during the Roman destruction of Jerusalem in $70 \mathrm{CE}$. The Western Wall is located in the Old City of Jerusalem. The wall has been a site for Jewish prayer and pilgrimage for centuries. David is an important figure in Judaism. Historically, David's reign represented the formation of a coherent Jewish kingdom centred in Jerusalem.
\end{abstract}

Key words: Jerusalem, Judaism, Herodian

\section{Úvod}

Súčasný judaizmus rozlišuje dva druhy pútnických miest, ktoré pri prílete do Izraela môžete navštívit'. Sú to v prvom rade pamätné miesta, ktoré majú dôležitú historickú hodnotu a spojitost’ s dejinami starého Izraela. Rovnako historickú hodnotu majú aj sakrálne miesta, ktoré vždy 
symbolizovali prepojenie židovskej religiozity so zjavením Boha Jahveho na hore Sinaj. Predstavená štúdia pojednáva o týchto dvoch typoch historických a náboženských miest akú hodnotu majú pre súčasných vyznávačov judaizmu i pre dejiny Izraela vo všeobecnosti a pre tých, ktorí putujú k týmto pamätným a svätým miestam v meste Jeruzalem.

\section{Pamätné miesta súčasného judaizmu}

JeruZalem - Židovská ŠTVRŤ, Herodiánska (Herodesova) ČAsŤ Židovská štvrt’ archeologicky nazývaná aj ako Herodiánska (Herodesova) čast’ patrí medzi najdôležitejšie historické a archeologické lokality starého Jeruzalema. ${ }^{1}$ Objavenie staveniska sa odohralo nečakane, ked' po skončení šest'dňovej vojny došlo k znovu výstavbe židovskej štvrti a súčasne s ňou začala rozsiahla príprava na komplexný archeologický výskum lokality. Výskum bol vykonaný počas rokov 1969-1982 pod záštitou Archeologického ústavu z Hebrejskej univerzity v Jeruzaleme v spolupráci s Izraelskou pamiatkovou správou. Z výsledkov archeologického výskumu môžeme uviest: ${ }^{2}$

- že, názov: Herodiánska (Herodesova) štvrt’ označuje stúpencov Herodesovej dynastie. Herodiáni mali v rukách celú vládnu moc a ako spolupracovníci Rimanov získavali dobré miesta v štátnej správe, ktoré boli aj patrične zaplatené.

- že, stavby pochádzajú z obdobia druhého chrámu.

- že, stavenisko je $6 \mathrm{~m}$ pod úrovňou dnešnej ulice.

- že, miesto pôvodného Horného mesta spomína už židovský historik Jozef Flavius ako lukratívne miesto západne od Jeruzalemského

1 MAJERNíK, J. - SCHEIdovÁ, L.: Spoznávajme Svätú zem pohladom archeológov a biblistov. Zákamenné: Rímskokatolícky farský úrad v Zákamennom, 2005. s. 142.

2 THE COMPANy FOR THE RECONSTRUCTION AND DEVElopment OF THE JEWISH QUARTER: The Jewish Quarter in the Old City of Jerusalem Ltd. http://www.jewish-quarter.org.il/atar-saruf.asp [4 IV 2011]. 
chrámu, pretože bolo vyššie než chrámová hora, ktorá mohla byt’ odtial' dobre videná.

- že, lokalita nesie znaky vypálenia v roku 70, mesiac po zničení Jeruzalemského chrámu.

- že, objavili sa tu celé komplexy kňazských a velkňazských palácov, ktoré patrili ich rodinám. Odkryté sú zvyšky 5 domov 2 až 3 podlažných spolu s palácom - ideálne miesta pre bohaté rodiny židovských kňazov, ktorý slúžili v chráme.

- že, historicky to bola zámožná a lukratívna štvrt' Jeruzalema, ktorého obyvatelia žili v rímskom štýle.

- že, boli odkryté schody so vstupnou halou, viaceré mozaikové podlahy, nádrže a rituálne kúpele nevyhnutné pre rituálnu čistotu, nádvoria, sklady, rôzne mozaiky a fresky a pod.

Archeologická lokalita sa dnes nachádza rovnako v starom meste Jeruzalema v židovskej štvrti na ulici Tiferet Jisrael. Celá oblast' sa stala častou múzea Herodiánskej štvrte. ${ }^{3}$ JERUZALEM - VypálenÝ dom Rodiny Kathros

Archeologická lokalita známa ako vypálený dom rodiny Kathros ${ }^{4}$ hebr. sa nachádza rovnako ako už spomínané objekty v židovskej

3 smugmug: The Burnt House (House of Kathros) An archeological site that was excavated between 1969 and 1982 that has been turned into a museum. http://aeroal.smugmug.com/ISRAEL-JNF-2007-Tour/Sunday-21st-October-Jerusalem/The-Burnt-House-House-of/4121016_Cy PA\#243487994_kVoo8 [4 IV 2011].

4 Rodina Kathros bola jednou zo štyroch rodín šlachtickej línie významných židovských kňazov a velkňazov, ktorí zneužívali svoje postavenie a moc v Jeruzalemskom chráme. Išlo o rodiny: dom Baithos, dom Hanin, dom Kathros, dom Ismael ben Piakhi. Týmto rodinám je zvlášt vyčítané, že lobisticky presadzovali ostatných rodinných členov, aby ich príslušníci dostali významné pozície v chráme. Zároveň je im vyčítaná, nenávist', nespravodlivost', útlak a zmluvné obohacovanie sa. Vel’mi negatívne o nich hovorí Babylonský Talmud, ktorý o rodinách, kde je zahrnutý aj dom Kathros s výstrahou hovorí: „Beda mne z domu Kathros, beda mne z ich (jedu) pier...Pretože sú to vysokí kňazi a ich synovia sú pokladníci, a ich zatovia sú správcovia a ich zamestnanci šlahajú ludí s palicami. BABYLONskÝ TALMUd - Talmud Balvi, Pesachim 57, 1. 
štvrti pôvodne Horného mesta v Jeruzaleme. Odkryté archeologické miesto budovy je označované prívlastkom vypálený, spálený alebo vyhorený dom Kathros, z dôvodu, že stavenisko pochádza z obdobia vypálenia Jeruzalema Rimanmi v roku 70 pri dobíjaní a vypálení mesta a chrámu pod vedením vojvodcu Títa. ${ }^{5}$ Vtedy bol dom zničený a ukrytý pod hrubou vrstvou popola ako zničená stavba podla artefaktov z rímskej doby. ${ }^{6}$ Preto táto lokalita nesie už aj spomínaný názov. Podla archeologických nálezov vypálený dom patril pravdepodobne židovskej aristokratickej kňazskej rodiny nazývanej Kathros a bol vystavaný počas obdobia druhého chrámu. V súčasnosti sa stavenisko nachádza šest’ metrov pod úrovňou dnešnej ulice v židovskej štvrti v starom Jeruzaleme, pretože rímska úroveň bola pochovaná postupnými vrstvami konštrukcií počas jednotlivých storočí.

Židovskí archeológovia objavili zničené veci, ktoré vyvolávali bolestivé spomienky na miesto, nakol'ko nájdené stavebné kamene boli čierne sadzami. Medzi nimi bol napríklad: spálený riad, spálené drevené krokvy a čierne steny. Sadza bola všade rovnako ako i na povrchu odkrývania. Archeológom odkrýval obraz, že sa tu nachádzal priestranný dom, ktorý sa prostredníctvom vypálenia zrútil a zasypal všetko, čo sa v ňom nachádzalo. Je zaujímavostou, že prof. Nachman Avigad, ktorý viedol vykopávky objavil dom presne 1900 rokov od jeho zničenia

In: THE COMPANY FOR THE RECONSTRUCTION AND DEVELOPMENT OF THE JEWISH QUARTER: The Burnt House of Kathros. Jerusalem: The Company for the Reconstruction and Development of the Jewish Quarter in the Old City of Jerusalem Ltd.

5 Heriban, J.: Príručný lexikón biblických vied. Bratislava: Vydavatel'stvo Don Bosco, 1998. s. 1169.

6 GEVA, H.: Stratigraphy and Architecture". In: Jewish Quarter Excavations in the Old City of Jerusalem IV. Jerusalem: Israel Exploration Society. s. 1-90.

7 THE COMPANY FOR THE RECONSTRUCTION AND DEVELOPMENT of The Jewish QuARTER: The Burnt House of Kathros. Jerusalem: The Company for the Reconstruction and Development of the Jewish Quarter in the Old City of Jerusalem Ltd. 
Rimanmi. Identifikácia archeologickej lokality bola taká významná, že množstvo ludí sa prišlo pozriet’ na významný objav. ${ }^{8}$

Pri archeologickom odkrývaní priestorov sa našla nádherná rezidencia, v ktorej sa nachádzalo vydláždené nádvorie, izby, malá kuchyňa a rituálna kúpelňa. Je to evidentné aj napriek tomu, že z pozostatkov sú už iba ruiny suterénu obsahujúce potreby pre domácnost', ktoré prežili ničenie ohňa. Suterén domu obsahuje malú dielňu ako objekt pre polnohospodárske potraviny, ktoré boli tam mleté, vážené, merané a pripravované na pokrm. ${ }^{9}$ Medzi nálezmi bol nájdený tažký kamenný balvan, na ktorom boli vytesané neucelené aramejské slová „Bar Kathros”, čo znamená „syn Kathrosa resp. „patriace synovi Kathrosa." Nápis sa dá identifikovat ako názov známej bohatej rodiny kňazov, ktorí slúžili v chráme. Na základe vykopávok archeológovia predpokladajú, že sa tu pravdepodobne nachádzalo sídlo a dielňa neslávne známej židovskej aristokratickej a kňazskej Kathrosovej rodiny. Vytesaný kamenný balvan sa najskôr používal na drvenie korenia pre kadidlo, ktoré kňazi používali pre služby chrámu. Kadidlo tak bolo pripravené a vážené práve $\mathrm{v}$ týchto priestoroch. ${ }^{10}$

Zrekonštruované boli štyri izby, kuchyňa, dvor a malá mikvah - rituálny kúpel. V troskách sa našli aj ramenné kosti mladej ženy, ktorá bola možno jednou z domu a ktorá zomrela rukou Rimanov. Ďalším zaujímavým predmetom, ktorý sa našiel je kovový oštep. Ten mohol byt’

8 smugmug: The Burnt House (House of Kathros) An archeological site that was excavated between 1969 and 1982 that has been turned into a museum. http://aeroal.smugmug.com/ISRAEL-JNF-2007-Tour/Sunday-21st-October-Jerusalem/The-Burnt-House-House-of/4121016_CYTPA\#243487994_kVoo8 [4 IV 2011].

9 THE COMPANY FOR THE RECONSTRUCTION AND DEVELOPMENT OF THE JeWish QUARTER: The Jewish Quarter in the Old City of Jerusalem Ltd. http://www.jewish-quarter.org.il/atar-saruf.asp [4 IV 2011].

10 THE COMPANY FOR THE RECONSTRUCTION AND DEVELOPMENT OF THE JEWISH QUARTER: The Burnt House of Kathros. Jerusalem: The Company for the Reconstruction and Development of the Jewish Quarter in the Old City of Jerusalem Ltd. 
používaný na obranu proti Rimanom. Dom bol súčastou väčšieho komplexu, ktorý bol umiestnený východne v blízkosti domu. Rozloha staveniska je asi 55 m štvorcových a zahŕňalo malé nádvorie, štyri izby, kuchyne a mikvah. Steny domu sú postavené z kameňov a cementu a sú pokryté hustou bielou omietkou. Zachovali až do výšky okolo jedného metra. ${ }^{11}$

$Z$ výsledkov archeologického výskumu môžeme uviest: ${ }^{12}$

- že, prof. Nachman Avigad, ktorý viedol vykopávky objavil dom presne 1900 rokov od jeho zničenia Rimanmi.

- že, stavenisko je z obdobia vypálenia Jeruzalema a dom bol ukrytý pod hrubou vrstvou popola.

- že, bol súčastou komplexu, patriaci kňazskej rodine Kathros.

- že, nájdené predmety sú pre každodenný život rodín ako sú: kamenné stoly a džbány, kuchynský riad, vo vnútri domu vidiet' kamenné poháre na vodu, kuchyňu, rituálne kúpele, pece a pracovné priestory, mince, nástroje, kamenné závažia (vrátane názvu rodiny) a d’alšie artefakty.

- že, v dome boli nájdené zvyšky kamenných tabuliek a mnohé keramické, kamenné a kovové nádoby, železné klince a všetko, čo zostalo $\mathrm{z}$ drevenej strechy. Police a vnútorné vybavenie boli úplne vyhoreté. Našli sa mince vydané guvernérmi Rímskej provincie Judea a iné položky domácnosti, velké džbány, misy a odmerky, čo naznačuje, že ide aj o dielňu na výrobu parfumov.

- že, medzi vykopané exempláre z rímskeho obdobia sú napríklad: olejové lampy, ktoré boli používané večer na osvetlenie domu a iné riady a kamenné závažia. ${ }^{13}$

11 GEVA, H.: Stratigraphy and Architecture". In: Jewish Quarter Excavations in the Old City of Jerusalem IV. Jerusalem: Israel Exploration Society. 2010. s. $1-90$.

12 SMUgmug: The Burnt House (House of Kathros) An archeological site that was excavated between 1969 and 1982 that has been turned into a museum. http:// aeroal.smugmug.com/ISRAEL-JNF-2007-Tour/Sunday-21st-October-Jerusalem/ The-Burnt-House-House-of/4121016_CY TPA\#243487994_kVoo8 [4 IV 2011].

13 THE COMPANY FOR THE RECONSTRUCTION AND DEVELOPMENT OF THE JEWISH QUARTER: The Jewish Quarter in the Old City of Jerusalem Ltd. http://www.jewish-quarter.org.il/atar-saruf.asp [4 IV 2011]. 
- že, rozloha staveniska je asi 55 m štvorcových, ktoré tvorí malé nádvorie, štyri izby, kuchyne a mikvah. Steny postavené z kameňov a cementu a sú pokryté hustou bielou omietkou. Zaachovali až do výšky $1 \mathrm{~m}$.

- že, je viditel’ná dielňa na príp5, ravu kadidla a iných komerčných položiek, ktoré boli predávané v blízkosti chrámu pútooooooooni$45 \mathrm{kom}$.

- Že, d’alšou nájdenou zaujímavostou je odvodňovací kanál, na ktorý sa v diele Židovská vojna sa odvoláva aj Jozef Flavius, pretože byty Horného mesta mali najmodernejší odvodňovací systém skladajúci sa $\mathrm{z}$ tunelov. Počas povstania proti Rimanom boli tieto podzemné siete používané na ukrývanie a tajnú komunikáciu. Zdá sa, že tunely objavené pod spáleným domom slúžili aj utekajúcim bojovníkom. ${ }^{14}$

V súčasnosti celá lokalita tvorí samostatné múzeum vypáleného domu Kathros. Nad lokalitou je postavený rezidenčný dom. Návštevníkom múzea je k dispozícii audiovizuálna prezentácia, ktorá slúži na zobrazenie časového okamihu posledných tragických udalostí z obdobia takmer 2000 rokov starých udalostí.

\section{Sakrálne miesta súčasného judaizmu}

Jeruzalem - Chrámová hora a ZápadnÝ múr, Múr PlaČu

Prvým a najdôležitejším sakrálnym miestom súčasného judaizmu je takzvaná Chrámová hora a na jej západnej strane zachovalí Západný múr známy aj ako Múr plaču. Celý komplex Chrámovej hory spolu so Západným múrom sú pre judaizmus sakrálnym miestom, o ktorom posvätné texty judaizmu neustále hovoria ako mieste kde je prítomný

14 Flavius, J.: Židovská vojna. Kniha vi. 5, 6, 8. In: Porov.: The company FOR THE RECONSTRUCTION AND DEVELOPMENT OF THE JEWISH QUARTER: The Burnt House of Kathros. Jerusalem: The Company for the Reconstruction and Development of the Jewish Quarter in the Old City of Jerusalem Ltd. 
Boh Izraela. Je to z dôvodu, že na tomto mieste stál Jeruzalemský chrám, z ktorého ostal už len spomínaný Západný múr. Počiatky chrámovej hory siahajú k miestu, kde podla židovskej tradície Abrahám obetoval svojho syna Izáka a miesto už od nepamäti bolo miestom Božej prítomnosti. Následne po prenesení Božej archy so zvyškami desatora do Jeruzalem sa mesto stalo náboženským centrom celého národa a sídelným mestom izraelských králov Dávida a Šalamúna ako sa uvádza, že „... tento Dávidov syn rozšíril mesto severným smerom cez vrch Ofel na vrch Moria, kde postavil prvý židovský chrám. Potom vystaval královský palác s trónnou stípovou sieňou a mesto obohnal múrmi."15 Posledný, kto urobil enormné zásahy do stavby chrámovej hory bol Herodes Velký. Ten zásadne rozšíril obnovil druhý Jeruzalemský chrám vybudovaný Zorobábelom v roku 515. pr. Kr. Herodes zároveň dal postavit stavby, ktoré boli typické pre grécko-rímsku kultúru. ${ }^{16}$ Po jeho smrti sa stupňovali spory s rímskou správou a vyvrcholili v Prvú židovskú vojnu, ktorá skončila definitívnym zničením Jeruzalemského chrámu v roku 70. Samotný Jeruzalem bol však obnovený za cisára Hadriána a dostal aj nový názov Colonia Aelia Capitolina s novým chrámom zasväteným pohanským bohom Zeusovi, Junone a Minerve. ${ }^{17} \mathrm{Z}$ miesta chrámu ostala iba západná stena - dnešný Západný múr - Múr nárekov. ${ }^{18}$

Západný múr - Múr nárekov je najposvätnejším miestom judaizmu na svete. Tento objekt má historicky niekolko pomenovaní: ${ }^{19}$

- Západný múr - hebrejsky nazývaný לתוכה יברעמה - Ha Kotel Ha Maarví, geografické označenie na základe polohy Jeruzalemského

15 MAJERník, J. - SCHEIdovÁ, L.: Spoznávajme Svätú zem pohladom archeológov a biblistov. Bratislava: Zakamenné, 2005. s. 71.

16 Tamże. s. 78.

17 HeRIBAn J.: Príručný lexikón biblických vied. Rím: PSUCM, 1992. s. 724725, 1091-1092.

18 The Westerm Wall heritage fundation: The Western Wall. Information on celebrating a Bar Mitzvah at the Western Wall: 1-599-515-888.

19 MAJERník, J. - SCHEIdová, L.: Spoznávajme Svätú zem pohladom archeológov a biblistov. Námestovo: Rímskokatolícky farský úrad v Zákamennom, 2005. s. 118. 
chrámu a názov zaužívaný od 6o. rokoch 20. storočia, nakol'ko sa jedná o lokalitu a miesto.

- Múr nárekov, Múr plaču - toto pomenovanie súvisí s literárnym druhom elégie a žalospevu. Elégia patrí medzi lyrické básne, ${ }^{20}$ v ktorej autor alebo prednášatel' oplakáva smrt' blízkej osoby, alebo sa oplakáva a trúchli nad neštastím, ktoré postihlo národ alebo osoby. $\mathrm{V}$ žalospevoch ako $\mathrm{v}$ modlitbách, ktoré sa modlili židia počas histórie sa jednotlivec alebo národ sa v tažkých životných situáciách, nebezpečenstvách obracal s prosbou na Boha prosiac ho o vyslobodenie, pomoc v súženiach. Inšpiráciou bola kniha Tanachu s názvom Náreky alebo Jeremiášové náreky (žalospevy), kde sa oplakáva zničenie Jeruzalema a chrámu v roku 587/6 pr. Kr. babylonskými vojskami. ${ }^{21} \mathrm{Z}$ tohto dôvodu mohlo vzniknú toto pomenovanie, ked’hlasné modlitby veriacich židov modliacich sa žalospevy pripomínali plač, pričom však išlo o určitý spôsob židovskej modlitby.

- Múr - hebrejsky nazývaný לתוכה - Ha Kotel jednoducho lingvisticky označený ako tento konkrétny jeden Západný múr, múr z Jeruzalemského chrámu.

- Het El Mabkach - arabské pomenovanie predmetnej geografickej lokality.

Západný múr patrí do lokality východného okraja historickej časti starého Jeruzalema nazývaného ako „staré mesto.” Z archeologického výskumu je známe, že: „...do roku 1967 mal dĺžku 48 m a výšku $18 \mathrm{~m}$. $V$ súčasnosti meria 85 m a popri rampe vedúcej na Chrámové návršie smeruje na juh a mierne na sever. Odkrytých je až 170 m a predpokladá sa, že 15 m múru sa nachádza ešte pod zemou a smeruje $k$ Via Dolorosa."22

20 GAVURA, J.: Lyrické iluminácie: kritiky a interpretácie 1997-2010. Prešov: Občianske združenie Slniečkovo, 2010. s. 52-68.

21 HeRIBAn J.: Príručný lexikón biblických vied. Rím: PSUCM, 1998. s. 537539.

22 MAJERník, J. - SCheidová, L.: Spoznávajme Svätú zem pohladom archeológov a biblistov. Námestovo: Rímskokatolícky farský úrad v Zákamennom, 2005. s. 119. 
Je to pravdepodobné, že je to jediná zachovalá čast’ vonkajšej západnej chrámovej hradby bývalého komplexu Jeruzalemského chrámu a upraveného chrámového návršia. Podla židovskej tradície je to čast’ opevnenia, ktoré siaha až do doby prvého Jeruzalemského chrámu, ktorý vybudoval Šalamún. Avšak táto tradícia sa nedá nijako autenticky doložit a ani overit', nakolko mesto bolo počas svojej histórie: „50-krát obliehané, 36-krát dobyté a 17-krát úplne zrovnané zo zemou." ${ }^{23}$ a znovu vybudované.

Pravdepodobnejšia je verzia, že sa jedná o čast’ z masívneho opevnenia, ktorá podopierala a obklopovala chrámové nádvorie druhého chrámu. Ten v roku 515 pr. Kr. židia po návrate z Babylonského exilu znovuvybudovali a nazvali tzv. druhý, resp. Zorobábelov chrám, ${ }^{24}$ ktorý neskôr prestaval a rozšíril až Herodes Velký. ${ }^{25}$ Takto prestavaný chrám patril medzi 7 divov starovekého sveta no jeho trvanie bolo krátke, nakolko v rokoch 68-70 po Kr. bol zničený a vypálený Rimanmi a z Jeruzalemského chrámu ostala už len spomínaná západná stena. Západný múr je tak poslednou existujúcou pamätou na neexistujúci Jeruzalemský chrám.

Nakol'ko Jeruzalemský chrám bol od počiatku na stránkach posvätných textoch Hebrejskej biblie miestom, kde sídli a prebýva Boh, chrám a jeho časti získali atribút svätosti. Ked’ v roku 70 bol chrám zničený a po rokoch 133-135 počas potlačenia Bar Kochbovho povstania následne židia mali zakázaný pobyt $\mathrm{v}$ Jeruzaleme postupne sa zo severných častí rozpŕchli do celého sveta.

Ale i tak sa k svojmu najsvätejšiemu miestu a k chrámovému návršiu sporadicky podla možnosti a slabosti zahraničnej politiky Ríma

23 GODfrey, FR: Pútnik vo svätej zemi. Nakladatel slov. versie: ThDr Ján Majerník: Published by Palphod Ltd., Majernik, 1994. s. 66.

24 Heriban j.: Príručný lexikón biblických vied. Rím: PSUCM, 1998. s. 537539.

25 MAJERník, J. - Scheidová, L.: Spoznávajme Svätú zem pohladom archeológov a biblistov. Námestovo: Rímskokatolícky farský úrad v Zákamennom, 2005. s. 118. 
v časoch uvol’nenia vracali a boli im dovolené prechodné návštevy. Vtedy vykonávali osobné modlitby v nádeji na prislúbenia uvedené na stránkach Hebrejskej biblie. Počas prvý storočí krestanstva až do 7. storočia táto oblast' bola pod správou Byzantskej ríše. Aj v tomto období im bolo dovolené, aby si raz v roku židia mohli pripomínat zničenie Jeruzalemského chrámu. Židia tak smeli vstúpit do Jeruzalema len raz do roka, aby sa mohli pomodlit pri Múre nárekov a žialit za strateným chrámom i mestom. ${ }^{26} \mathrm{Z}$ tohto obdobia pochádza aj prvý záznam datovaný do roku 333 z údajov rozprávaní krestanského pútnika z Bordeaux, ktorý si vykonal pút k svätým miestam. Zachytené údaje hovoria o smútočných modlitbách židov konaných na tomto mieste aj v súvislosti s modlitbami prináležiacich na spomienku 9. dňa mesiaca Av. ${ }^{27}$

Počas expanzie islamu boli vztahy medzi islamom a judaizmom viac pozitívne ako negatívne. V 7. storočí bola čast' Západného múru rekonštruovaná moslimskou dynastiou - Umajovcami, ktorý vládli v Arabskom kalifáte v rokoch 660-750. ${ }^{28}$ Avšak táto rekonštrukcia bola zemetrasením v 11. storočí poškodená. Počas obdobia križiackych výprav a obsadenia Jeruzalema krestanmi nemali židia velké možnosti navštívit' chrámové návršie a pozostatky Západného múra. Situácia sa však zmenila po odchode križiackych vojsk zo Svätej zeme. V tomto období nastalo pre židov obdobie náboženského uvol’nenia a bol im dovolený prístup ku chrámovému návršiu a k spomínanému múru. Nakol'ko pre moslimov nepredstavovali židia žiadne nebezpečenstvo postupne začal Západný múr mat’ charakter osobitného svätého a pútnického miesta. Avšak v 13. storočím platil už pre židov oficiálny

26 Dejiny sveta. Bratislava: Slovart, 1996. s. 75.

27 9. Av je spomienka na zničenie Jeruzalemského chrámu Babylončanmi a v roku 587/6 pr. Kr a Rimanmi v roku 70. STERn, M.: Svátky v živote židů. Praha: Vyšehrad, 2002. s. 218-219.

28 MAJERník, J. - SCHeidová, L.: Spoznávajme Svätú zem pohladom archeológov a biblistov. Námestovo: Rímskokatolícky farský úrad v Zákamennom, 2005. s. 118-119. 
moslimský zákaz návštev Západného múru, predsa sa uskutočnili viaceré neoficiálne návštevy za určitý poplatok. Obmedzenie sa skôr týkalo chrámovej plošiny než časti, kde sa nachádzal Západný múr. Tu možno priradit' aj d’alšiu existujúcu zmienku z roku 1488 o putovaniach a návštevách židov pri Západnom múre. Tento oficiálny zákaz platil vo všeobecnosti až do Prvej svetovej vojny. V 16. stor. noví osmanskí sultáni uskutočnili určité renovácie na chrámovej hore a spolu s rekonštrukciou boli v rokoch 1537-1540 postavené brány a múry mesta tureckým sultánom Sulejmanom a zachované sú dones.

V 19. storočí je evidentný rozmach politického a náboženského sionizmu. V tomto hnutí aj Západný múr mal svoje špecifické miesto a to tým, že na jednej strane bol historickým znakom rozpŕchnutých a vytlačených židov po celom svete ako symbol židovskej diaspóry a na strane druhej predstavoval miesto stretnutia a putovania všetkých roztrúsených židov po celom svete. ${ }^{29}$ Múr sa stal symbolom národnej obrody s nádejou na zriadenie vlastného štátu. ${ }^{3 \circ}$

20. storočie prinieslo na poli geopolitickom viaceré zmeny. Po prvej svetovej vojne územie Palestíny bolo pod správou britského mandátu (1918-1948). Židia tak mohli k Západnému múru neoficiálne prichádzat', nakolko Britskou vládou neboli stanovené žiadne oficiálne obmedzenia. V tom čase existovala vlna návratu velkého množstva židovských rodín spät do vlasti, čo vyvrcholilo v roku 1948 založením Štátu Izrael. Nakolko v tom čase nebol založený aj Palestínsky štát a územie pripadlo Jordánsku napätie v oblasti medzi arabským a židovským etnikom vyvrcholilo opätovným zákazom vstupu židov k Západnému múru. Tento zákaz bol zrušený až v roku 1967, ked' po 6 dňovej vojne ${ }^{31}$ získal Štát Izrael viaceré územia a Západný múr sprístupnili, opravili

29 The Westerm WALl heritage fundation: The Western Wall. Information on celebrating a Bar Mitzvah at the Western Wall: 1-599-515-888.

30 SHUBERT, K.: Židovské náboženství v proměnách věkư. Praha: Vyšehrad, 2010. s. 236.

31 Viedol ju Izraelský štát napadnutý Egyptom, Jordánskom a Sýriou. Vojna sa skončila vítazstvom Izraela, ktorý si pripojil Sinajský polostrov, Golanské 
a rozšírili. ${ }^{32}$ Námestie pred múrom bolo vypratané, umožňujúce všetkým prichádzajúcim pútnikom samotný prístup. Múr sa tak stal jedinečným miestom modlitby a symbolom židovskej národnej jednoty. ${ }^{33}$

Západný múr - Múr nárekov má okrem historickej hodnoty aj dôležité miesto $v$ náboženskom a liturgickom živote súčasného judaizmu. Jeho chápanie vychádza z hodnoty, aké má toto miesto, chrámová hora a jeruzalemský chrám na stránkach posvätných spisoch judaizmu a ich interpretáciách. ${ }^{34}$ „Pri návšteve tohto miesta si musite uvedomovat, že pre judaizmus je to najsvätejšie miesto na svete, miesto, kde podobne ako na pôvodnom chráme, spočiva prítomnost' Jahveho na zemi. Západný múr sa stal prírodnou funkčnou modlitebňou, miestom národnej a náboženskej identity Židov. Slúži ako náboženské, kultúrne, duchovné a sociálne centrum svetového židovstva. Považuje sa za ortodoxnú synagógu po otvoreným nebom. Západný múr je pútnickým miestom, miestom náboženských úkonov, modlitieb, prosieb i verejných pobožností. Je zároveň symbolom záchrany a spásy."35

Nakol'ko je priestor celého námestia a priestor pod budovami pri Múre nárekov považovaný za synagógu od návštevníkov a pútnikov týchto svätých miest sa vyžadujú striktné náboženské pravidlá ako sa dôstojne správat a pravidlá týkajúce sa odievania rovnako pre židov, prozelytov, nežidovských alebo krestanských návštevníkov: ${ }^{36}$

výšiny a západný breh Jordánu. MAJERNík, J. - SCHEIDovÁ, L.: Spoznávajme Svätú zem pohladom archeológov a biblistov. 2005. s. 769.

32 MAJERník, J. - SCHEIdová, L.: Spoznávajme Svätú zem pohladom archeológov a biblistov. Námestovo: Rímskokatolícky farský úrad v Zákamennom, 2005. s. 118-119.

33 The Westerm Wall heritage fundation: The Western Wall. Information on celebrating a Bar Mitzvah at the Western Wall: 1-599-515-888.

34 Gavura, J.: Pohansky obradná, krestansky čistá. In: Romboid: literárnokritický mesačník. Roč. 35, č. 3 (2000). s. 69-70.

35 Newman, J. - Sivan, G.: Judaizmus od a do z. Praha: Sefer, 2009. s. 90.

36 the Westerm Wall heritage fundation: The Western Wall. Information on celebrating a Bar Mitzvah at the Western Wall: 1-599-515-888.; MAJERNÍK, J. - SCHEIDOVÁ, L.: Spoznávajme Svätú zem pohladom archeológov a biblistov. 2005. s. 119. 
- čast' pre mužov sa nachádza na lavej strane, pričom muži vstupujú na sväté miesto s pokrývkou na hlave nazývanou ako kipa alebo jarmulka. ${ }^{37}$ Tá je k dispozícii na stolíku spolu s inými modlitebnými knihami. Žid je povinný nosit jarmulku pri modlitbe a pri štúdiu Tóry. Od 16.-17. storočia nosia mnohí veriaci židia jarmulku neustále..$^{38}$

- čast’ pre ženy sa nachádza na pravej strane, pričom ženy musia mat zahalené ramená a lýtka. $\mathrm{K}$ tomu sú pre návštevníkov a pútnikov $\mathrm{k}$ dispozícii na pripravenom stolíku šatky na obviazanie okolo ramien a pása.

- čast̉ vyčlenená na štúdium Tóry a Tanachu je pokračujúcou častou zasahujúca do vnútra po pravej strane postavených budov tak sa pozdľž pokračujúceho múra sa vytvorilo vhodné miesto aj na štúdium Tóry, ktoré je výhradne vyčlenené pre mužov. Vytvoril sa tak vhodný priestor pre modlitby a čítanie zo zvitkov Tóry, tak ako to bolo kedysi pri chrámových školách. ${ }^{39}$

- modlitbový priestor je priestor pri a pred samotným múrom. Ako už bolo spomenuté k dispozícii sú modlitbové knihy, ktoré sú v hebrejskom a anglickom jazyku. Spôsob modlitby pred múrom je v judaizme charakteristický tým, že modliaci stojí vyrovnaný pred múrom a kolíše sa dopredu a dozadu alebo sa jednoducho len dotýka rukou alebo čelom múra. Je to pre judaizmus charakteristický spôsob, že veriaci židia sa modlia nielen ústami, srdcom a myslou, ale celým svojím telom. Po skončení vizitácie spravidla zahraniční návštevníci vkladajú do špár a dier v múre modlitbové papieriky, kde sú uvedené ich najdôležitejšie prosby a vyznania viery predkladané Bohu počas modlitby.

- všeobecný priestor je priestor, kde sa vykonávajú niektoré náboženské slávenia sviatkov a židovských náboženských obradov ako

37 Jarmulka alebo Kipa, je okrúhla židovská čiapočka, ktorá pokrýva temeno hlavy a môže byt pripnutá $\mathrm{k}$ vlasom kovovou sponkou.

38 Cestovanie: Jeruzalem II: Tam, kde sa modlí a narieka, http://cestovanie.aktuality.sk/dovolenka/celorocne/2-cast-jeruzalem-tam-kde-sa-modlia-narieka/ [4 IV 2011].

39 Tamże. 
je slávnost' dospelosti známa ako Bar micvah. Toto miesto je pre židov sakrálnym miestom modlitby a osobného stretnutia s Bohom, miestom pre štúdium a čítanie Tóry, miestom slávenia náboženských a liturgických slávností a viacerých národných akcií ako sú: vel'ké židovské sviatky Pésach a Sukkot, Simchat Torah, sprievod sviečok na sviatok Chanuky, alebo sú to prísahy nováčikov ozbrojených síl Izraela a Izraelskej polície, slávenia v pamätné dni a deň slávnosti Jeruzalema. Počas sobotňajšieho dňa - Jom Šabbat a počas židovských sviatkov sa zároveň dodržiava zákaz fajčenia, fotografovania a používania akejkolvek technickej komunikácie v oblasti Západného múra.

Vonkajší priestor pred Západným múrom podlieha taktiež špecifickým pravidlám. Do areálu sa vstupuje po dôkladnej osobnej kontrole každého návštevníka a pútnika. Pred samotným múrom je vydláždené väčšie priestranstvo rozdelené na vstupnú a modliacu sa čast', a miesto sa neustále udržuje v čistote, bez zelene nakolko je to pre židovský národ sakrálny priestor. Vstupný priestor do sekcie pre mužov a ženy má formu zväčšeného námestia. To umožňuje dôstojný vstup do obidvoch modlitebných častí. Okolo celého priestranstva je možné vidiet’ viacerých vojakov, ktorý sa starajú o bezpečnost', poriadok a zachovanie dôstojnosti sakrálneho miesta. ${ }^{40}$ "Na jednom z blizkych domov umiestnili 6 lámp, a tie by mali pripomínat' 6 miliónov Židov, ktorí zahynuli počas holokaustu. Je tu stanica prvej pomoci, zdroje pitnej vody i hygienické zariadenia, a žiadne schody."11 Na samotnom mieste v rámci liturgických a náboženských obradov je potrebné zachovávat ticho a pokoj.

Západný múr - Múr nárekov je pre turistov a pútnikov najnavštevovanejšie miestom v Izraeli. Zaujímavostou je to, že k múru majú prístup aj nežidia. Z nich je najviac možné stretnút práve krestanov rôznych

40 Príspevky na udržovanie a rozvoj areálu Západného múru môžu byt vykonané do určených zberných boxov alebo vás kompetentný s takýmto boxom oslovia o príspevok.

41 MAJerník, J. - SCHeidovÁ, L.: Spoznávajme Svätú zem pohladom archeológov a biblistov. 2005. s. 119. 
denominácií, ktorý častokrát s velkou úctou a prosbami prichádzajú na too sväté miesto judaizmu. ${ }^{42}$

\section{JeruZalem - DÁvidova hrobka}

Najväčším a najvýznamnejším králom v histórii Izraelského národa bol král' David. Dávid sa usadil v Jeruzaleme v10. storočí pr. Kr. a mesto Jeruzalem urobil náboženským a politickým strediskom Izraelského náro$d a$ ako je o tom známe z nasledujúceho textu: „Dávid, využil strategickú polohu mesta ale i to, že sa nachádza na rozhraní území severných kmeňov a kmeňa Júdu, čím sa mesto stalo akoby nadštandardným a nikomu $z$ týchto kmeňov nepatriacim mestom. Pádom pevnosti Sion sa dostalo i celé mesto do područia Joabovi a jeho vojakom. Pevnost' Sion sa premenovala na Dávidovo mesto a tam sa usadil i Dávid s celou svojou rodinou a svojou suitou."43

Zároveň podla biblickej tradície bol pochovaný v meste Dávidovom, ktorému pôvodne zodpovedala rozloha vrchu a pohoria Sion. Aj ked' dnes nie je jasné, kde sa presne hrob krála Davida nachádza je to s najväčšou pravdepodobnostou lokalita mesta Jeruzalem. Biblická tradícia textov Starého zákona sa odvoláva na dva nasledujúce texty:

- „Potom sa Dávid uložil k svojim otcom a pochovali ho v Dávidovom meste." (1 Kr 2, 10) Dávidove mesto sa tak stáva synonymom pre mesto Jeruzalem.

- v Novom zákone existuje taktiež spomienka na hrob krála Dávida a to v prípade Petrovej reči k obyvatelom Jeruzalema, kde v jeden jej časti hovorí: „Bratia, dovolte mi otvorene vám povedat o praotcovi Dávidovi, že zomrel, pochovali ho a jeho hrob je u nás až do dnešného dňa." (Sk 2, 29). Ked' Peter povedal na Sione spominanú kázeň, hovoril $v$ nej aj o hrobe krála Dávida. ${ }^{44}$

42 the Westerm Wall heritage fundation: The Western Wall. Information on celebrating a Bar Mitzvah at the Western Wall: 1-599-515-888.

43 Kostol svatej roiny v trenčíne: Dávid v Jeruzaleme. http://www. ksrtn.sk/ksrtn_biblia.php?strana=15 [10 IV 2015].

44 KRAJČI, J.: Izrael (Svätá Zem). Pezinok: INKA, 2000. s. 107. 
Z toho je evidentné, že miesto pochovania krála Dávida sa nachádza $v$ meste Jeruzalem. Teda niekde v lokalite Jeruzalema je určite hrob Dávida, kde presne, to sa nevie. Biblia síce nehovorí presne o umiestnení hrobu, ale uvádza, že miesto odpočinku krála Dávida bolo vo vnútri opevnenia Dávidovho mesta. ${ }^{45}$ „Krestania ako prví postavili symbolický hrob a kostol na pamiatku tohto krála $v$ byzantskom období 324-64o po Kr. a ked' ho niekto zničil, znova ho obnovovali. Križiaci v 12 stor. po Kr. postavili svätyne $v$ dvoch úrovniach na predchádzajúcich krestanských stavbách. Po ich odchode objekt spravovali františkáni a roku 1335 po Kr. ho znova opravili. Ked'v 15. stor. po Kr. zvitazila povest'o velkom poklade krála Dávida začali sa uchádzat’o pravdepodobné miesto jeho hrobu stúpenci islamu a neskôr i judaizmu. Mamluci roku 1551 po Kr. vyhnali františkánov a objekt Večeradla vyvlastnili krestanom a prestavali na mešitu. Nazvali ju mešitou proroka Dávida nazývanej Nabi Daud, kde nedovolili krestanom ani vstúpit. Zákaz vstupu trval až do roku $1948 .{ }^{346}$

Preto je dnes Dávidov hrob iba symbolický. ${ }^{47}$ Zaujímavostou je, že podla židovskej tradície na miesto upozornil uzdravený slepec a podla tradície už viac ako 200 rokov sem putujú židia, aby si uctili pamiatku krála Dávida. Izraelská vláda tak upravila toto symbolické miesto na Sione ako prázdny kamenný hrob, sarkofág - kenotaf - symbolický prázdny hrob, ${ }^{48}$ ktorý pokryli purpurovo-červeným vyšívaným súknom s typickými symbolmi harfy a okolo sú aj posvätné texty Tóry. Návšteva hrobu krála Dávida je možná za rovnakých podmienok aké sú určené pri vstupe Západnému múru. Vstup pre mužov a pre ženy je rovnako oddelený, pričom musí byt taktiež dodržaný určitý „kódex

45 Brosnahan, T. - Ullian, R.: Jeruzalém průvodce do kapsy. Bučovice: RO-TO-M, 200O. S. 49.

46 MAJERník, J. - SCHeIdovÁ, L.: Spoznávajme Svätú zem pohladom archeológov a biblistov., 2005. s. 221.

47 KRAJČI, J.: Izrael (Svätá Zem). Pezinok: INKA, 2000. s. 107.

48 majerník, J. - scheidová, L.: Spoznávajme Svätú zem pohladom archeológov a biblistov. Námestovo: Rímskokatolícky farský úrad v Zákamennom, 2005. s. 761 . 
odievania”. Mužom musí zdobit' hlavu jarmulka, nakol'ko aj toto miesto je pre súčasný judaizmus dôležitým svätým a pútnickým miestom. Vedla miesta Dávidovho hrobu je funkčná synagóga. Židia sa prichádzajú modlit do Dávidovej hrobky počas celého roka, obzvlášt však cez Šavout spájaný s Dávidovou smrtou. ${ }^{49}$ Paradox spočíva v tom, že je to rovnaké sväté miesto ako majú krestania, pretože na poschodí sa nachádza Večeradlo, kde Ježiš Nazaretský posledný krát večeral so svojimi učeníkmi.

\section{Zoznam použitej literatúry}

BABylonský talmud - Talmud Balvi, Pesachim 57, 1. In: The COMPANY FOR THE RECONSTRUCTION AND DEVELOPMENT OF THE JEWISH QUARTER: The Burnt House of Kathros. Jerusalem: The Company for the Reconstruction and Development of the Jewish Quarter in the Old City of Jerusalem Ltd.

Brosnahan, T. - Ullian, R.: Jeruzalém průvodce do kapsy. Bučovice: RO-TO-M, 2000.

CeStOVAnie: Jeruzalem II: Tam, kde sa modlí a narieka.

http://cestovanie.aktuality.sk/dovolenka/celorocne/2-cast-jeruzalem-tam-kde-sa-modli-a-narieka/ [4 IV 2011].

Dejiny sveta. Bratislava: Slovart, 1996.

flavius, J.: Židovská vojna. Kniha vi. 5, 6, 8. In: Porov.: The Company FOR THE RECONSTRUCTION AND DEVELOPMENT OF THE JEWISH QUARTER: The Burnt House of Kathros. Jerusalem: The Company for the Reconstruction and Development of the Jewish Quarter in the Old City of Jerusalem Ltd.

GAVura, J.: Pohansky obradná, krestansky čistá. In: Romboid: literárnokritický mesačník. Roč. 35, č. 3, (2000).

49 Godfrey, F.: Pútnik vo svätej zemi. Nakladatel' slov. versie: ThDr Ján Majerník: Published by Palphod Ltd., s. 78. 
GAVURA, J.: Lyrické iluminácie: kritiky a interpretácie 1997-2010. Prešov: Občianske združenie Slniečkovo, 2010.

GEVA, H.: Stratigraphy and Architecture". In: Jewish Quarter Excavations in the Old City of Jerusalem IV. Jerusalem: Israel Exploration Society. GODFREY, FR: Pútnik vo svätej zemi. Nakladatel' slov. versie: ThDr Ján Majerník: Published by Palphod Ltd., Majernik, 1994. HeRIBAn, J.: Príručný lexikón biblických vied. Bratislava: Vydavatelstvo Don Bosco, 1998.

KRAJČI, J.: Izrael (Svätá Zem). Pezinok: INKA, 2000.

kostol SVATej roiny v trenčíne: Dávid v Jeruzaleme. http://www. ksrtn.sk/ksrtn_biblia.php?strana=15 [4 IV 2011].

MAJERNík, J. - SCHeidová, L.: Spoznávajme Svätú zem pohladom archeológov a biblistov. Zákamenné: Rímskokatolícky farský úrad v Zákamennom, 2005.

newman, J. - sivan, G.: Judaizmus od a do z. Praha: Sefer, 2009.

smugmug: The Burnt House (House of Kathros) An archeological site that was excavated between 1969 and 1982 that has been turned into a museum. http://aeroal.smugmug.com/ISRAEL-JNF-2007Tour/Sunday-21st-October-Jerusalem/The-Burnt-House-Houseof/4121016_CYTPA\#243487994_kVoo8 [4 IV 2011].

STERN, M.: Svátky v živote židů. Praha: Vyšehrad, 2002.

SHUBERT, K.: Židovské náboženství v proměnách věkư. Praha: Vyšehrad, 2010. THE COMPANY FOR THE RECONSTRUCTION AND DEVELOPMENT OF THE JEWISH QUARTER: The Jewish Quarter in the Old City of Jerusalem Ltd. http://www.jewish-quarter.org.il/atar-saruf.asp [4 IV 2011]. THE COMPANY FOR THE RECONSTRUCTION AND DEVELOPMENT OF THE JEWISH QUARTER: The Burnt House of Kathros. Jerusalem: The Company for the Reconstruction and Development of the Jewish Quarter in the Old City of Jerusalem Ltd.

THE WESTERM WALl HeRitage FUndation: The Western Wall. Information on celebrating a Bar Mitzvah at the Western Wall: 1-599$515-888$. 